\title{
Deregulation and Privatisation of the Upstream and Downstream Oil and Gas Industry in Nigeria: Curse or Blessing?
}

\author{
Abu Ikponmwosa Noruwa \\ Department of Finance \\ Faculty of Business Administration \\ University of Lagos, Nigeria \\ Tel: +23-480-2819-2007_E-mail: abuikponmwosa@yahoo.com \\ Chidi Odogwu Christopher (Corresponding author) \\ Department of Industrial Relations and Personnel \\ Management, Faculty of Business Administration \\ University of Lagos, Nigeria \\ Tel: +23-480-2303-4213_Ｅ-mail: krischidi2002@yahoo.com
}

Received: July 29, 2011

doi:10.5430/ijba.v3n1p16
Accepted: October 13, 2011 Published: January 5, 2012

URL: http://dx.doi.org/10.5430/ijba.v3n1p16

\begin{abstract}
The purpose of this study is to examine the perception of Nigerians on the deregulation and privatisation moves of the government in the oil and gas industry in Nigeria. The oil and gas industry is strategic to national development and growth in Nigeria. Oil and gas constitute about $90 \%$ of Nigeria's foreign exchange earnings and $83 \%$ of its GDP. This study adopted the survey research design. It was found that the deregulation and privatisation of the oil and gas industry will usher in sustainable national development and will be a blessing rather than a curse for the citizenry. $77.8 \%$ of the respondents believe that the deregulation and privatisation of the oil and gas industry will be a blessing to Nigerians and $80.6 \%$ of the respondents do not believe that the deregulation and privatisation of the oil and gas industry will be a curse to Nigerians. The authors recommend that strategic sectors such as oil and gas as well as the power sector should be deregulated and privatised for sustainable national development.
\end{abstract}

Keywords: Deregulation, Privatisation, Upstream, Downstream, Oil and Gas Sector, Curse, Blessing

\section{Introduction}

The oil and gas industry is strategic to national development and growth in Nigeria. Oil and gas constitute about $90 \%$ of Nigeria's foreign exchange earnings and 83\% of its GDP (Ogbeifun, 2008). According to Adewumi and Adenugba (2010), Nigeria is one of the world's largest producers of crude oil, the $10^{\text {th }}$ largest producer and the $6^{\text {th }}$ largest exporter among Organisation of Petroleum Exporting Countries (OPEC) members. Nigeria, Africa's largest crude exporter has continued to import refined petroleum products after over fifty years of crude oil extraction (Nwanze, 2007). Many hold the view that for the oil and gas sector in Nigeria to satisfy the yearnings and aspirations of the citizenry the sector should be deregulated and privatised. Deregulation and privatisation are now global phenomena. They are the offshoot of economic globalisation. Many developed and developing countries have experienced one form of economic reforms or the other as a result of the global economic system. The attitude of some Nigerians towards deregulation and privatisation of the oil and gas industry has been indifferent as many hold the notion that such government policies will lead to job losses as well as high cost of living. This negative attitude or posture; poses the greatest problem to the Nigerian economy. Many have argued that the non- deregulation and non- privatisation of the sector will lead to negative consequences such as wanton diversion of petroleum products to neighbouring countries, smuggling, hoarding and other criminal activities perpetrated in the system. The country has four oil refineries and these refineries have been bedevilled by fire, sabotage, poor management, lack of turn-around maintenance as well as corruption. These challenges have made it difficult for the refineries to operate beyond 40 percent of their capacities (Adewumi \& Adenugba, 2010). The consequence of the catalogue of problems listed above is usually shortages of refined products and massive 
importation to meet domestic consumption. It is believed in some quarters that the deregulation and privatisation of this strategic sector will bring succour to Nigerians and make the products readily available and cheap since it would breed competition as we have witnessed in the telecommunications sector. The deregulation of the telecommunications sector in Nigeria gave way for more competition and eventually lower charges or tariffs. However, the average Nigerians' belief is that the deregulation and privatisation of the oil and gas industry will result in hikes in the prices of petroleum products. The objective of deregulation and privatisation of the oil and gas industry is to enable private investors to invest in the sector in other to eliminate constant shortages of fuel and gas in the country. From experience it appears that government can not manage this strategic sector for sustainable development in Nigeria. Efforts being made to deregulate down streams oil and gas sector are welcome relief to the sector and Nigerians generally. There has been crisis in this strategic sector. The crisis has resulted in production shutdowns, high cost of obtaining fuel from the black market and scarcity or unavailability of petroleum products. This has had negative impacts on the economy with industrial capacity utilisation nose-diving drastically. Many companies operating in Nigeria have relocated their businesses to other neighbouring countries as a result of the high cost of petroleum products as many rely on generating sets to power their operations. The deregulation and privatisation of this industry will reduce constant shortages and reduce time wasting in queues for fuel at filling stations. We are all living witnesses to the dramatic changes that have taken place in the telecommunications sector and the quantum leap that has been achieved in this sector. The oil and gas free-zone in Onne, Rivers state; is a welcome development. However, since the oil and gas sector is capital intensive in nature and requires foreign technologies, the government should give adequate incentives for private sector participation.

The purpose of this study is to examine the perception of Nigerians on the deregulation and privatisation moves of the government in the oil and gas industry in Nigeria.

\section{Literature Review}

To deregulate as defined by the Oxford Advanced Learner's Dictionary (2005) means to free a trade, a business activity from rules and controls; that is to decontrol whilst to privatise means to sell a business or an industry so that it is no longer owned by the government; that is to denationalise. Deregulation as defined by investorwords.com means the removal of government controls from an industry or sector to allow for a free and efficient marketplace. Deregulation occurs when the government seeks to allow more competition in an industry that allows near-monopolies. Deregulation enhances competitive service delivery that will enable consumers to have wide range of choices as regards their quest for satisfaction. A glaring example can be seen in the telecommunication sector (Omodia, 2007). As noted by the World Bank (1988), experience has shown that competitive markets- mainly involving private sectors are the most efficient ways to supply goods and services. Government role usually can be limited to policy making, while leaving actual investment, operation and maintenance to non-governmental entities (Omodia, 2007). According to Onipede (2003) the continuous abysmal performances by most of the government parastatals are the undisputable evidences of inappropriateness of government involvement in business. Onipede further asserts that those who continuously argue against NEPA's now PHCN's privatisation cited loss of jobs and national security as reasons. Rational minds would definitely disagree with this reasoning. Thus, deregulation and privatisation are believed to be capable of enhancing efficiency and effectiveness in service delivery.

According to Olayiwola (2009), oil and gas operations commenced in Nigeria effectively in 1956. A brief historical excursion indicates that oil exploration started in 1908 in Lagos and Okitipupa coastal areas both in Western Nigeria by the Nigerian Bitumen Company established by a German Consortium. Between 1908 and 1956, various exploration and exploitation continued in various parts of Nigeria. In 1956, oil was discovered in commercial quantity at Oloibiri, present day Bayelsa state (Ihua, Ajayi \& Eloji, 2009); in the Niger Delta region of Nigeria by Shell D'Arcy. This development heralded Nigeria's membership of Organisation of Petroleum Exporting Countries (OPEC) in 1971. The exploration of oil and gas is predominantly concentrated in the Niger Delta where multinational companies and a few of the indigenous ones are engaged in production and exploration of oil and gas. The oil and gas industry comprises the upstream, the downstream and service sectors. The upstream sector focuses on mining, exploration, production and exportation and is dominated by multinational companies (Ogbeifun, 2009). Chevron, Shell, Agip, Elf, Texaco, Esso-Mobil inter alia belong to the upstream sector. According to Adewumi and Adenugba (2010), these multinational companies weld so much power within the Nigerian state and the communities. They have been able to exploit, explore and produce oil within the Niger region axis without corresponding development. A few indigenous upstream oil and gas companies exist in line with the provision of local content policy of the government. The downstream sector is involved in refining of crude oil into usable products through distillation, conversion and other special treatments to arrive at petroleum products and gas. It is also involved in distribution of products. The downstream sector has been constrained by unenviable state of the refineries, which have been producing at minimal capacities despite huge 
expenses incurred on turnaround maintenance of the crisis-ridden refineries (Aigbedion \& Iyayi, 2007). Petrochemical plants and fuel stations belong to this sector. The service sector provides technical and consultancy services to aid the upstream sector in drilling, exploration and production activities. The Nigerian government is a major investor in the production activities of the upstream sector and its activities are co-ordinated mainly by the Nigerian National Petroleum Corporation (NNPC). The Department of Petroleum Resources (DPR) acts as the regulatory agency for the oil and gas sector. Aside from the NNPC and the DPR, the Ministry of Energy, the Federal Ministry of Environment, the Federal Inland Revenue Service and the Niger Delta Development Commission are the principal government agencies responsible for oil and gas matters in Nigeria (Chidi, Badejo \& Ogunyomi, 2011).

\section{Method}

This study adopted the survey research design. With a view to eliciting information from respondents, a self-developed questionnaire was designed using the dichotomous scale (Yes/No). The instrument has two sections: Section A has 13 items which sought the views of respondents on the deregulation and privatisation of the upstream and downstream oil and gas industry in Nigeria. Section B elicited the demographic profile of respondents. A total of 215 questionnaires were distributed to the target population using the simple random sampling technique. The questionnaires were self-administered to respondents with the help of three research assistants. However, 180 were returned upon which the data analysis was based. This represents $83.7 \%$ response rate. Data analysis was carried out with the aid of SPSS (Statistical Package for Social Sciences) version 17.

\section{Results}

With respect to respondents' category, respondents to this survey consist of government agencies which represent $22.2 \%$ of the respondents. Market women make up 16.7\%; students $12.2 \%$; workers account for $19.4 \%$; upstream oil sector comprises $16.1 \%$; whilst the downstream oil sector consists of $13.3 \%$. With respect to sex distribution, $68 \%$ of the respondents are male whilst $32 \%$ are female.

$78 \%$ of respondents are not in support of the monopoly enjoyed by the NNPC. This implies that they are in support for the deregulation of the oil and gas industry which will break the monopoly of NNPC. 67\% of the respondents believe that deregulation and privatisation of the oil and gas industry will force down the prices of petroleum products. $82 \%$ of the respondents believe that deregulation and privatisation will result in the elimination of smuggling of petroleum products across the borders to neighbouring countries. $78 \%$ of the respondents believe that the deregulation and privatisation have nothing to do with political factor except if the government is not sincere with its policy implementation. $88 \%$ of respondents agree that deregulation and privatisation policies will improve the Nigerian economy. 86\% of respondents do not agree that the political implications outweigh the economic implications for deregulation and privatisation. This corroborates the views of respondents to the preceding question. 94\% of the respondents agree that the government should go ahead with deregulation and privatisation of the oil and gas industry.

$50 \%$ of the respondents agree that the removal of fuel subsidy is necessary whilst $50 \%$ disagree. $72.2 \%$ agree that government should subsidise the prices of petroleum products. $100 \%$ of the respondents believe that the deregulation and privatisation of the oil and gas industry will create job opportunities for Nigerians. $67 \%$ of the respondents think that the government should deregulate and privatise the oil and gas industry gradually. $77.8 \%$ of the respondents believe that the deregulation and privatisation of the oil and gas industry will be a blessing to Nigerians. $80.6 \%$ of the respondents do not believe that the deregulation and privatisation of the oil and gas industry will be a curse to Nigerians. This corroborates the views of respondents to the preceding question.

\section{Discussion of Findings}

From the foregoing, it is evident that the deregulation and privatisation of the oil and gas industry will usher in sustainable national development and will be a blessing rather than a curse for the citizenry. These findings are consistent with the views of Omodia (2007). According to Omodia (2007) government role usually can be limited to policy making, while leaving actual investment, operation and maintenance to non-governmental entities. Omodia (2007) views deregulation and privatisation in positive light as it is believed that deregulation and privatisation are capable of enhancing efficiency and effectiveness in service delivery.

\section{Conclusion and Recommendations}

Deregulation and privatisation are now global phenomena. They are the offshoot of economic globalisation. For an economy to be competitive it needs to embrace global standards. We cannot escape globalisation and so we must be part of it. The attitude of some Nigerians towards deregulation and privatisation of the oil and gas industry has been indifferent as many hold the notion that such government policies will lead to job losses as well as high cost of living. This negative attitudinal posture; poses the greatest problem to the Nigerian economy. It was found that the deregulation 
and privatisation of the oil and gas industry will usher in sustainable national development and will be a blessing rather than a curse for the citizenry. The following recommendations are made:

- The authors recommend that strategic sectors such as oil and gas as well as the power sector should be deregulated and privatised for sustainable national development.

- It is recommended that the regulatory framework and environment should be such that encourage maximum competition. Accordingly, government must repeal all laws that inhibit competition and should pass laws that protect investors.

- Government should prepare to address the labour problems, which may arise as a result of deregulation and privatisation. A proactive programme of education of labour unions should be pursued. More so, safeguards against job losses should be embarked upon.

- It is recommended that government should leave the management of company in the hands of the strategic partner.

- Government sales option (of $40 \%$ to strategic partner, $20 \%$ Nigerian public and $40 \%$ government) should be implemented accordingly even at the reduced equity holding by government. However it is recommended that government divests gradually its remaining shares at a minimum of $5 \%$ per year to the Nigeria public.

- It is recommended that workers should be allowed to have a stake in the refineries in the form of equity participation. This will reduce the risk of shortage usually associated with workers' union activities and ensure greater commitment to the survival of the refineries.

- It is recommended that the government should in effect provide the broad guidelines for the operation of the refineries and allow private initiative in the running of refineries.

\section{References}

Adewumi, F. \& Adenugba, A. (2010). The State of Workers' Rights in Nigeria: An Examination of the Banking, Oil and Gas and the Telecommunication Sectors. Abuja: Friedrich Ebert Stiftung

Aigbedion, I \& Iyayi, S. E. (2007). Diversifying Nigeria’s Petroleum Industry. Nigerian Economic Summit Group (NESG) Economic Indicators.Vol.13 No.4; pp.41-50

Chidi, O. C., Badejo, A. E., \& Ogunyomi, P. O. (2011). Collective Bargaining Dynamics in the Upstream Oil and Gas Industry: The Nigerian Experience. Presented at the $6^{\text {th }}$ African Regional Congress of the International Labour and Employment Relations Association (ILERA) on Emerging Trends in Employment Relations in Africa: National and International Perspectives, organised by the Nigerian Industrial Relations Association and held at the University of Lagos from the $24^{\text {th }}-28^{\text {th }}$ of January, 2011. [Online] Available: http://www.ilo.org/public/english/iira/documents/congresses/regional/lagos2011/4 ${ }^{\text {th }}$ session/session4a/collecti vebargaining.pdf.

Hornby, A.S. (2005). Oxford Advanced Learner's Dictionary. ( $7^{\text {th }}$ ed.). UK: Oxford University Press

Ihua, U.B., Ajayi, C. \& Eloji, K.N (2009). Nigerian Content Policy in the Oil and Gas Industry: Implications for Small and Medium-sized Oil Services Companies. Proceedings of the $10^{\text {th }}$ Annual Conference.IAABD

Nwanze, K.O. (2007). The Nigerian Petroleum Downstream Sector and Product Pricing: Issues and the Way Forward. Nigerian Economic Summit Group (NESG) Economic Indicators.Vol.13 №.4; pp.51-57

Ogbeifun, L.B. (2009). Oil and Gas Industry Reforms: Issues and Challenges for Trade Unions. Paper Presented at the Warri Zonal Workshop of NUPENG Held at the Labour House Asaba, Delta State, 11th September

Ogbeifun, L.B. (2008). Labour Crises in the Oil and Gas Sector: Challenges to Development in the Oil and Gas Sector. Paper Presented at a Workshop Organised by NIM, Jos.

Olayiwola, A. (2009). History of Nigerian Oil and Gas Industry. [Online] Available: http://www.pengassan.org/pdf/History of Nigerian Oil and Gas Industry.pdf

Omodia, S.M. (2007). Problems and Prospects of Deregulation in the Nigerian Fourth Republic: Implication for Democratic Survival in Nigeria. Medwell Journal of International Business Management.1 (2), pp.43-46

Onipede, S. (2003). Towards Creating an Environment for Sustainable Economic Growth in Nigeria, International Experience. [Online] Available:

http://www.nigerdeltacongress.com/tarticles/towards_creating_an_environment.htm 
World Bank (1988). Policy Research Report

Table 1. Frequency Distribution of Primary Data N=180

\begin{tabular}{|c|c|c|c|c|c|}
\hline $\mathrm{S} / \mathrm{N}$ & QUESTIONS & YES & $\%$ & NO & $\%$ \\
\hline 1 & $\begin{array}{l}\text { Should the monopoly enjoyed by the NNPC be } \\
\text { sustained? }\end{array}$ & 40 & $22 \%$ & 140 & $78 \%$ \\
\hline 2 & $\begin{array}{l}\text { Will the deregulation and privatisation of the } \\
\text { oil and gas industry force down the prices of } \\
\text { petroleum products? }\end{array}$ & 120 & $67 \%$ & 60 & $33 \%$ \\
\hline 3 & $\begin{array}{l}\text { Will the deregulation and privatisation result } \\
\text { in the elimination of smuggling the product } \\
\text { across the border? }\end{array}$ & 148 & $82 \%$ & 32 & $18 \%$ \\
\hline 4 & $\begin{array}{l}\text { Do you agree that there are political } \\
\text { implications for deregulation and privatisation } \\
\text { policies? }\end{array}$ & 40 & $22 \%$ & 140 & $78 \%$ \\
\hline 5 & $\begin{array}{l}\text { Do you agree that deregulation and } \\
\text { privatisation policies will improve the } \\
\text { Nigerian economy? }\end{array}$ & 158 & $88 \%$ & 22 & $12 \%$ \\
\hline 6. & $\begin{array}{l}\text { Do you agree that the political implications } \\
\text { outweigh the economic implications for } \\
\text { deregulation and privatisation? }\end{array}$ & 25 & $14 \%$ & 155 & $86 \%$ \\
\hline 7. & $\begin{array}{l}\text { Do you agree that the government should go } \\
\text { ahead with deregulation and privatisation of } \\
\text { the oil and gas industry? }\end{array}$ & 170 & $94 \%$ & 10 & $6 \%$ \\
\hline 8 & $\begin{array}{l}\text { Do you agree that the removal of fuel subsidy } \\
\text { is necessary? }\end{array}$ & 90 & $50 \%$ & 90 & $50 \%$ \\
\hline 9. & $\begin{array}{l}\text { Do you agree that government should } \\
\text { subsidise the prices of petroleum products? }\end{array}$ & 130 & $72.2 \%$ & 50 & $\begin{array}{l}27.8 \\
\%\end{array}$ \\
\hline 10 & $\begin{array}{l}\text { Do you believe that deregulation and } \\
\text { privatisation of the oil and gas industry will } \\
\text { create job opportunities for Nigerians? }\end{array}$ & 180 & $100 \%$ & - & - \\
\hline 11 & $\begin{array}{l}\text { Do you think that the government should } \\
\text { deregulate and privatise the oil and gas } \\
\text { industry gradually? }\end{array}$ & 120 & $67 \%$ & 60 & $33 \%$ \\
\hline 12 & $\begin{array}{l}\text { Do you believe that the deregulation and } \\
\text { privatisation of the oil and gas industry will be } \\
\text { a blessing to Nigerians? }\end{array}$ & 140 & $77.8 \%$ & 40 & $\begin{array}{l}22.2 \\
\%\end{array}$ \\
\hline 13 & $\begin{array}{l}\text { Do you believe that the deregulation and } \\
\text { privatisation of the oil and gas industry will be } \\
\text { a curse to Nigerians? }\end{array}$ & 35 & $19.4 \%$ & 145 & $\begin{array}{l}80.6 \\
\%\end{array}$ \\
\hline
\end{tabular}

Source: Field Survey, 2011

NB: See section on Results for the description of table 1 